Науковий вісник НЛТУ України Scientific Bulletin of UNFU http://nv.nltu.edu.ua

https://doi.org/10.15421/40290309

Article received $29.03 .2019 \mathrm{p}$.

Article accepted $25.04 .2019 \mathrm{p}$.

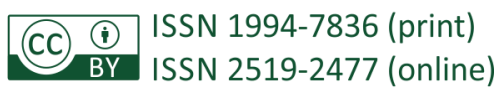

$@ \bowtie$ Correspondence author

E. M. Rizun

rizun_elia@ukr.net

удк 630*2[502.7+591.9]

О. В. Паламаренко, Е. М. Різун

Національний лісотехнічний університет Украӥни, м. Львів, Украӥна

\title{
ТВАРИННЕ НАСЕЛЕННЯ ДЕНДРАРІЮ БОТАНІЧНОГО САДУ НЛТУ УКРАЇНИ
}

Проведено оригінальні польові дослідження видового складу мезофауни підстилки і наземних хребетних тварин для дендрарію НЛТУ України у 2003-2019 рр. Спостереження за хребетними здійснено у всі сезони, а відбір проб - у червні та липні. Дослідженнями охоплена уся територія заповідного об'єкта. Кількість наземної мезофауни підстилки дендрарію знизилась, зменшилося також таксономічне різноманіття. Відзначено новий вид молюсків - іспанський слизняк. Цей представник безхребетних за останні два роки став дуже численним - його виявляли по всій території, а кладки яєць у підстилці знаходили навіть у жовтні. З'ясовано, що досліджена ділянка найпривабливіша для горобиних птахів 3 погляду гніздування, ночівлі та живлення. Тут відзначено 23 види птахів, з яких 56 \% за типом гніздування належать до кронників, а 14 \% - до дуплогніздників. Звірів виявлено тільки чотири види. Оптимальні умови тут для вивірки (Sciurus vulgaris), куниці кам'яної (Martes foina), миші хатньої (Mus musculus) та пацюка сірого (Rattus norvegicus). Хутро місцевих вивірок має різне забарвлення - $є$ руді особини і тварини чорного кольору. Колекція вікових дерев і декоративних чагарників зумовила формування особливого й унікального фауністичного комплексу дендрарію. Отримані результати можна використовувати для подальшого збереження унікального складу флори і фауни в урбанізованому середовищі міста Львова.

Ключові слова: птахи; ссавці; наземна мезофауна; антропогенний вплив.

Вступ. Зміни в рослинному покриві, посилення або ж послаблення захисних і кормових властивостей фітоценозів міських територій прямо чи опосередковано впливають на склад, динаміку популяцій і поширення тваринного населення (Klausnyttser, 1990; Kucheriavyi, 1999). Міське середовище є еволюційно новим і специфічним для життя тварин. Це зумовлено розчленуванням цілісності рослинного покриву на "острівці" з природними та штучними біотопами, відмінним від природного рослинним світом, а також- видозміненням кормової бази. Все це призводить до проникнення на урбанізовані території нових видів, пришвидшення видового обороту, зниження стабільності складу, значної кількості свійських та синантропних тварин, а як наслідок - до зниження ймовірності відновлення природних популяцій (Tatarynov, 1991; Zahorodniuk, 2003). Одним 3 основних чинників, що визначає видову різноманітність і щільність населення лісових тварин, зокрема птахів, є структура насаджень та розвиток рослинності (Rohatnova, 2001).

Активне дослідження тваринного населення Львова i його околиць розпочалося 3 кінця 40 -х років $\mathrm{XX}$ ст. Зокрема К. А. Татаринов дослідив видовий склад і синантропізацію наземних хребетних Львова і західного регіону України (Tatarynov, 1952, 1973, 1991). 3 кінця 80 -х років XX ст. зростас інтерес до вивчення герпетота теріофауни Львова і подають видові списки та деякі закономірності поширення земноводних і плазунів в умовах урбанізованого ландшафту (Polushna \& Shaitan,
1991; Fedoniuk, 2004). Більшість робіт щодо пристосувань фауни до урбанізованого середовища, стосуються орнітофауни (Luhovaia \& Huzyi, 1991). Теріофауна міста, кількісний і якісний склад наземних хребетних і мезофауни підстилки досі вивчені слабо, відомості подано в поодиноких публікаціях (Tatarynov, 1973; Polushyna, 1996; Rizun, 2003). Спеціальних досліджень тваринного населення дендрарію Ботанічного саду Національного лісотехнічного університету України (НЛТУ України) досі практично не проведено. Тому вивчення сучасного складу тваринного населення і його динаміки в часі на цій території $\epsilon$ актуальним.

Дендрарій розташований у центральній частині Львова, поблизу навчального корпусу № 3 по вул. О. Кобилянської, 1. Його було закладено у 1874 p. На невеликій площі $(0,81$ га) зосереджено велику кількість рідкісних і типових видів місцевої та світової флори, але більшість видів у колекції дендрарію - це інтродуценти, завезені з Японії, Китаю, Кавказу, Близького Сходу, Північної Америки. 3434 колекційних примірників деревно-чагарникової флори деревні види становлять 190 прим., кущі - 234 прим., ліани - 10. Серед них 108 примірників (29 таксонів) - хвойні, а 326 (151 таксон) листяні (Kucheriavyi, 2009; Kendzora, 2017).

Мета роботи - встановлення змін якісного складу тварин, які поширені на території дендрарію Ботанічного саду НЛТУ України у період з 2003 по 2019 рр. Головні завдання: 1) проаналізувати динаміку якісного i кількісного складу наземної мезофауни; 2) дослідити

\section{Інформація про авторів:}

Паламаренко Ольга Вікторівна, канд. біол. наук, ст. викладач, кафедра лісівництва. Email: olgapal1982@gmail.com

Різун Ельвіра Миколаївна, канд. с.-г. наук, доцент, кафедра лісівництва. Email: rizun_elia@ukr.net; https://orcid.org/0000-00020797-1681

Цитування за ДСту: Паламаренко О. В., Різун Е. М. Тваринне населення дендрарію ботанічного саду НЛту України. Науковий вісник НЛТУ України. 2019, т. 29, № 3. С. 44-47.

Citation APA: Palamarenko, O. V., \& Rizun, E. M. (2019). Animal population of the arboretum of the botanical garden of Ukrainian National Forestry University. Scientific Bulletin of UNFU, 29(3), 44-47. https://doi.org/10.15421/40290309 
якісний склад наземних хребетних, встановити екологічні групи, до яких вони належать, а також ступінь адаптації до урбанізованого середовища. Об'єкт дослідження - мезофауна підстилки та наземні хребетні тварини. Предмет дослідження - зміни тваринного населення дендрарію за останні 16 років.

Матеріали і методи дослідження. Дослідження проводили на території дендрарію Ботанічного саду НЛТУ України впродовж 2003-2019 pр. Вагому частину інформації зібрано під час літніх польових практик.

Аналіз якісного і кількісного складу тваринного населення дендропарку проведено шляхом спостережень за тваринами, слідами їх життєдіяльності (екскременти, пір'я), голосовою активністю птахів. Дослідження безхребетних наземної мезофауни проводили відбором проб підстилки на майданчиках розміром $25 \times 25$ см і вибору із них всіх безхребетних у лабораторних умовах Підстилка дендрарію має потужність 1-2 см; одношарова; складена 3 листя й опаду видів дерев, які ростуть у місці іiї накопичення; пухка; слабозчеплена; слабо з'єднана 3 грунтом; вкриття грунту осередкове (50 $70 \%$ ). Зібраних тварин фіксували у $70 \%$-му розчині спирту. Належність видів до конкретної трофічної або топічної групи визначено за літературними джерелами.

Результати дослідження. Тип підстилки, зокрема такі іiі характеристики, як склад, товщина, зчепленість та ін. відіграє визначальну роль у формуванні якісного і кількісного складу безхребетних, а також доступності їх як кормових об'єктів для птахів. На території дендрарію поширена підстилка типу муль, яку вважають найдоступнішою $з$ погляду добування корму комахоїдними птахами.

Таблиця. Якісний склад наземної мезофауни підстилки дендрарію (прим./м²)

\begin{tabular}{|c|c|c|}
\hline \multirow{2}{*}{ Таксон } & \multicolumn{2}{|c|}{ Pік } \\
\cline { 2 - 3 } & 2003 & 2016 \\
\hline Lumbricomorpha & 18,7 & 1,0 \\
\hline Opilionida & 8,0 & - \\
\hline Araneae & 16,0 & 1,5 \\
\hline Isopoda & 5,3 & - \\
\hline Lithobiomorpha & 5,3 & 4,0 \\
\hline Julidae & 13,3 & - \\
\hline Polydesmidae & - & 1,0 \\
\hline Hemiptera & 13,3 & 4,5 \\
\hline Mecoptera & 2,7 & - \\
\hline indet. Coleoptera & 8,0 & 0,5 \\
\hline Carabidae & 5,3 & - \\
\hline Staphylinidae & 21,3 & 1,0 \\
\hline Pythidae & 2,7 & - \\
\hline Coccinellidae & 2,7 & - \\
\hline Curculionidae & 5,3 & 0,5 \\
\hline Hymenoptera & 2,7 & - \\
\hline Formicidae & 50,7 & 30,5 \\
\hline Diptera & 5,3 & - \\
\hline Mollusca & 40,0 & 2,0 \\
\hline Bcьoго & 226,7 & 46,5 \\
\hline
\end{tabular}

Порівняння якісного і кількісного складу наземної мезофауни у 2003 і 2016 pp. (таблиця) свідчить, що 3 2003 по 2016 рр. кількість наземної мезофауни підстилки зменшилася 3 226,7 до 46,5 прим./м², кількість таксонів безхребетних тварин також зменшилася - від 18 до 10. У 2003 р. за чисельністю переважали мурашки (For-

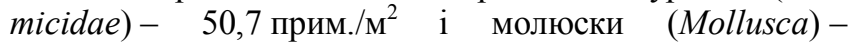
40,0 прим./м², дещо меншою була чисельність жуківстафілінід (Staphylinidae) - 21,3 прим./м² і дощових червів (Lumbricomorpha) - 18,7 прим./м². У 2016 р. налічувалось 30,5 прим./м² мурашок і 4,5 прим./м² напівтвер- докрилих (Hemiptera). Це пов'язано з порушенням підстилки у процесі утримання заповідного садово-паркового об'єкта, зокрема із скошуванням і утилізацією трави, а також впливом кліматичних (температура, кількість опадів) i антропогенних (забруднення території викидами автомобільного транспорту) чинників.

У 2017 р. на території дендрарію вперше зареєстровано небезпечний інвазійний вид черевоногого молюска - слизняк іспанський (Arion lusitanicus). Влітку та восени 2018 р. реєстрували сотні дорослих і молодих особин цього виду, а в жовтні 2018 р. - свіжі кладки яєць. Висока плодючість молюска і швидкі темпи розмноження призведуть в подальшому до небажаних екологічних наслідків. Їх відчують як місцеві види тварин, так і рослини заповідного об'єкту.

Земноводних і плазунів на території дендрарію не виявлено, що пов'язано із значною ізольованістю цього біотопу, антропогенним пресом, а також відсутністю водойм, придатних для розмноження і проживання перших. Окрім цього, плазуни $\epsilon$ найчутливішою групою тварин до процесу урбанізації природного середовища.

Птахи, як наймобільніша частина населення наземних хребетних міських насаджень, здатні за короткий час заселяти усі придатні для життя біотопи. Окрім цього, птахи є групою тварин, яка найбільше пов'язана iз зеленими насадженнями. Для дендрарію, які і для інших парків центральної частини міста Львова, поряд 3 невисокою видовою насиченістю, характерна висока чисельність окремих видів.

У 2003 р. на території дендрарію обліковано 10 видів гніздової орнітофауни, серед них: горлиця садова (Streptopelia decaocto), дятел звичайний (Dendrocopos major), сойка (Garrulus glandarius), кропив'янка чорноголова (Sylvia atricapilla), горихвістка звичайна (Phoenicurus phoenicurus), дрізд чорний (Turdus merula), синиця блакитна (Parus caeruleus), повзик (Sitta europaea), горобець хатній (Passer domesticus). За типом гніздування переважали дуплогніздники (40\%) і кронники (40 \%), по $10 \%$ - птахи приземно-чагарникового типу і синантропи. Трофічна спеціалізація розподілялась так: комахоїдні (70 \%), рослиноїдні (20\%) і всеїдні (10\%). За сезонною ритмікою переважали осілі види (50\%), перелітних - $30 \%$, а кочових - $20 \%$. Згідно 3 класифікацією наземних хребетних за ступенем адаптації до приміських і міських насаджень Львова (Різун, 2001), на 2003 р. серед птахів переважали мезогемерофіли (50\%), частка гемерофілів і еугемерофілів становила відповідно 30 і $20 \%$.

Упродовж 2017-2019 рр. зареєстровано таких представників гніздової і зимової орнітофауни: припутень (Columba palumbus), голуб сизий (Columba livia), горлиця садова, дятел звичайний, дятел середній (D. medius), сойка, сорока (Pica pica), галка (Corvus monedula), грак (C. frugilegus), омелюх (Bombycilla garrulus), кропив'янка чорноголова, вільшанка (Erithacus rubecula), чикотень (Turdus pilaris), дрізд чорний, дрізд-омелюх (T.viscivorus), дрізд співочий (T. philomelos), синиця блакитна, синиця велика (P. major), гаїчка-пухляк ( $P$. montanus), повзик, зяблик (Fringilla coelebs), костогриз (Coccothraustes coccothraustes), яструб малий (Accipiter nisus). Видова різноманітність виявлених птахів з 2003 по 2019 рр. збільшилася від 10 до 23 видів. Така висока різноманітність, порівняно 3 попереднім періодом, пов'язана з обліком у 2017-2019 рр. не тільки гніздових, 
але й зимуючих видів, а також привабливістю видового складу чагарникових порід дендрарію для харчування птахів у зимовий період, їх підгодівлею. У 2017 2019 pр. не виявлено горобця хатнього та горихвістку звичайну, які були обліковані в попередній період. За типом гніздування переважають кронники (56 \%), дуплогніздників $22 \%$, птахів приземно-чагарникового ярусу $-14 \%$, а наземногніздних і синантропних видів - по 4 \%. Порівняно з 2003 р. збільшилася частка кронників і зменшилася - дуплогніздників, що пов'язано із вилученням дуплистих дерев на території дендрарію. За трофічною спеціалізацію переважають комахоїдні птахи (61\%), рослиноїдних і всеїдних - по 17 \%, а 4 \% припадає на хижих птахів. Насіння хвойних порід дерев приваблює дятлів із паркових насаджень Львова, які розташовані недалеко від дендрарію (Стрийський парк, ПК т В ім. Б. Хмельницького, парк Цитадель, Ботанічний сад ЛНУ ім. І. Франка).

Фоновими видами птахів для території дендрарію варто вважати голуба сизого, сойку, сороку, дрозда чорного, чикотня, костогриза, припутня, горлицю садову, грака, галку, синицю блакитну і велику, повзика. Гнізда птахів приземно-чагарникового ярусу виявлено в основному на кущах сніжноягідника. У 2017-2019 рр. у складі населення птахів переважають мезогемерофіли (48 \%), частка гемерофілів і еугемерофілів становить відповідно 22 і $17 \%$, найнижчою є частка олігогемерофілів - 13 \%. На території дендрарію переважають види птахів, усі стадії життєвого циклу яких можуть проходити в біотопах зі сильним і помірним антропогенним впливом, але максимальної чисельності популяції виду досягають у біотопах, де антропогенний вплив мінімальний або відсутній.

Для птахів надзвичайно важливу роль відіграють дерева заввишки понад 20 м. У їх кронах зростають десятки кущів омели, що приваблюють рослиноїдних птахів. Скупчення дрібних горобиних птахів регулярно відзначали також у кронах тису ягідного. Рештки плодів тису ягідного виявлено і в екскрементах куниці кам'яної. Птахи в дендрарії, незважаючи на достатню кормову базу, є найвразливішою групою, оскільки зазнають прямого антропогенного впливу, зокрема чиннику турбування і винищення свійськими котами.

У 2003 р. на території дендрарію було обліковано три види ссавців, які належали до ряду Мишоподібні (Muriformes): вивірка звичайна, миша хатня і пацюк мандрівний (сірий). Вивірка мешкає на обстеженій території багато десятиліть поспіль, має тут надійні укриття і чудову кормову базу. Виявлено особини, забарвлені у рудий і чорний кольори. Миша хатня і пацюк сірий $є$ типовими еугемерофілами, тобто видами, усі стадії життєвого циклу яких проходять у біотопах з максимальним антропогенним впливом (Різун, 2001). Вивірка звичайна належить до мезогемерофілів. За період спостережень ситуація зі складом населення ссавців майже не змінилася, до наведених вище видів додався представник родини мустелових (Mustelidae)- куниця кам'яна. Вказані види знаходять на території дендрарію необхідні умови для сховищ, харчування і розмноження, окрім цього, відбуваються постійні міграції миші хатньої, пацюка мандрівного і куниці кам'яної між навчальними корпусами, господарськими спорудами дендрарію і прилеглими житловими будинками. Ссавці на території дендрарію $є$ найменш вразливою групою тва- рин, за винятком вивірки звичайної, яку переслідують свійські коти.

\section{Висновки:}

1. 32003 по 2016 рр. кількість наземної мезофауни підстилки дендрарію зменшилася від 226,7 до 46,5 прим./м²; подібну ситуацію спостережено і щодо таксономічного різноманіття (зменшення від 18 до 10); переважаючим таксоном є родина Formicidae. У 2017 р. вперше для території дендрарію зареєстровано небезпечний інвазійний вид - слизняк іспанський.

2. Земноводних і плазунів на території дендрарію не виявлено, що пов'язано із значною ізольованістю цього біотопу, антропогенним пресом, а також відсутністю місць, придатних для розмноження.

3. Видова різноманітність населення птахів з 2003 по 2019 рр. збільшилася від 10 до 23 видів за рахунок обліку не тільки гніздових, але й зимуючих видів. За зазначений період збільшилася частка кронників, зменшилася - дуплогніздників. На території дендрарію переважають види птахів, усі стадії життєвого циклу яких можуть проходити в біотопах зі сильним і помірним антропогенним впливом.

4. Населення ссавців з 2003 по 2019 рр. збільшилося від трьох до чотирьох видів, серед них переважають еугемерофіли. Порівняно 3 птахами, ссавці дендрарію $€$ менш вразливою групою, оскільки активно мігрують у пошуках корму і сховищ.

\section{Перелік використаних джерел}

Fedoniuk, O. V. (2004). Zemnovodni ta plazuny lisiv Lvivshchyny. Protected case in Galicia, Podillya and Volyn: scientific bulletin, 14(8), 386-392. Lviv: UkrDLTU. [In Ukrainian].

Kendzora, N. Z. (2017). Dendrarii Botanichnoho sadu NLTU Ukrainy $\mathrm{v}$ kompleksnii pidhotovtsi fakhivtsiv lisovoho i sadovo-parkovoho hospodarstva. Aktualni problemy ozelenennia naselenykh mists: osvita, nauka, vyrobnytstvo, mystetstvo formuvannia landshaftu: Materials of the 3rd International Scientific and Practical Conference, (pp. 72-73). Bila Tserkva, May 25-26. Retrieved from: http://science.btsau.edu.ua/sites/default/files/tezy/tezy mignarod k onf_ozelenen.pdf. [In Ukrainian].

Klausnittcer, B. (1990). Ekologiia gorodskoi fauny. Moscow: Mir, 246 p. [In Russian].

Kucheriavyi, V. P. (1999). Urboekolohiia. Lviv: Svit, 360 p. [In Ukrainian].

Lugovaia, L. A., \& Guzii, A. I. (1991). Osobennosti naseleniia nekotorykh grupp bespozvonochnykh zhivotnykh i ptitc $\mathrm{v}$ gorodskom landshafte razlichnoi stepeni urbanizatcii. Okhrana $i$ vosproizvodstvo ptitc prigorodnykh lesov $i$ zelenykh nasazhdenii, 43-44. Lviv. [In Russian].

Polushyna, N. A. (1996). Systema "horod-chelovek-zhyvotnoe" y ee optymyzatsyia (na prymere Lvova). Urbanizovane navkolyshnie seredovyshche: okhorona pryrody ta zdorovia liudyny, 215-219. Kyiv. [In Russian].

Polushyna, N. A., \& Shaitan, S. V. (1991). Zemnovodni ta plazuny Lvova i yikh okhorona. Problemy urboekolohii ta fitomelioratsii: Abstracts of Scientific and Practical Conference, (p. 144). Lviv: Publishing House LLTI. [In Ukrainian].

Rizun, E. M. (2001). Pro adaptatsii nazemnykh khrebetnykh do umov ubanizovanoho seredovyshcha. City gardens and parks: past, present, future, 11(5), 383-386. Lviv: UkrDLTU. [In Ukrainian].

Rizun, E. M. (2003). Optymizatsiia umov isnuvannia nazemnykh khrebetnykh u prymiskykh i miskykh nasadzhenniakh. Abstract of Candidate Dissertation for Agricultural Sciences (06.03.03 - Silvics and Forestry). Lviv: Ukrainian State Forestry University, 19 p. [In Ukrainian].

Rohatnova, E. M. (2001,a). Struktura nasadzhen yak faktor formuvannia naselennia nazemnykh khrebetnykh (na prykladi buchyn kompleksnoi zelenoi zony m. Lvova). Scientific Bulletin of NAU. Ser. Forestry, 39, 163-171. Kyiv. [In Ukrainian]. 
Tatarynov, K. A. (1952). Narys fauny ssavtsiv derevnykh nasadzhen raionu mista Lvova. Naukovi zapysky Pryrodnychoho muzeiu Instytutu ahrobiolohii AN URSR, 2, 92. Kyiv: Publishing House AN URSR. [In Ukrainian].

Tatarynov, K. A. (1973). Fauna khrebetnykh zakhodu Ukrainy. Lviv: Publishing House of Lviv University, 257 p. [In Ukrainian].
Tatarynov, K. A. (1991,b). Fauna urbanizovanoho otochennia ta ekolohichni adaptatsii vydiv. Problemy urboekolohii ta fitomelioratsii: Abstracts of Scientific and Practical Conference, (p. 33). Lviv: Publishing House LLTI. [In Ukrainian].

Zahorodniuk, I. V. (2003). Dyka teriofauna Kyieva ta yoho okolyts i tendentsii yii urbanizatsii. Vestnyk zoolohyy, 37(6), 29-38. [In Ukrainian].

O. V. Palamarenko, E. M. Rizun

Ukrainian National Forestry University, Lviv, Ukraine

\section{ANIMAL POPULATION OF THE ARBORETUM OF THE BOTANICAL GARDEN OF UKRAINIAN NATIONAL FORESTRY UNIVERSITY}

An important task for zoologists, ecologists, foresters, other scientists is the study of the systematic diversity of animals in the territory of protected objects. The authors of the publication have provided new and extremely valuable data about birds, animals, and some invertebrates, which are found on the territory of the arboretum. The species variety of animals is constantly undergoing changes caused by anthropogenic activity. During the studies, we noticed an increase of both the amount of ground-based mesophauna of arboretum and taxonomic diversity. In particular, a new dangerous species of mollusks - the Spanish snail (Arion lusitanicus) - has appeared at the object where the research was conducted. For the first time, researchers registered it there in 2017. Now this mollusk is massive and numerous throughout the territory. During the breeding season and nesting, migrations and wintering, most of the passerines were observed. The arboretum was not attractive concerning the animals. Only typical for inhabited locality and the most numerical rodents, such as house mouse (Mus musculus) and the brown rat (Rattus norvegicus) live there. Squirrels (Sciurus vulgaris) find conditions for feeding, reproduction and permanent residence to be favourable there. The researchers identified animals with red and black furs. Beech marten (Martes foina) was registered in 2017, and in October 2018 presence of beech marten was confirmed with excrements. The arboretum faunistic complex is unique and not well studied. The authors conducted personal observations in different seasons for a long period of time. We have found that birds are best represented here - more than 20 species and only five species of mammals were registered. Trees with a height of over 20 meters are important for birds. They are attractive because valuable and nutritious seeds and fruits. Walnut, magnolia, beech, oak, and pine are especially important. Bird cherry, dogwood and other plant species are also valuable for food. Mistletoe, a parasitic plant, and common yews (Taxus baccata) attract herbivorous birds with their fruits. Martens eat the fruits of the common yew (Taxus baccata). The results of the research should be the basis for the implementation of specific environmental measures for the most vulnerable local animal species.

Keywords: birds; mammals; terrestrial mesofauna; anthropogenic influence. 